\title{
Vascular occlusion in a previously unaffected territory after treatment with intravenous plasminogen activator: illustrative case
}

\author{
Akira Sugie, MD, PhD, ${ }^{1,3}$ Makoto Yamada, MD, PhD, ${ }^{1}$ Kunio Yokoyama, MD, $\mathrm{PhD},{ }^{1}$ Tomoaki Miyake, $\mathrm{MD},{ }^{2}$ Yutaka Ito, $\mathrm{MD},{ }^{1}$ \\ Hidekazu Tanaka, MD, PhD, ${ }^{1}$ Yukiya Nomura, MD, PhD, ${ }^{3}$ Masutsugu Fujita, MD, PhD, ${ }^{3}$ Toshio Nakatani, MD, PhD, ${ }^{3}$ and \\ Masahiro Kawanishi, MD, $\mathrm{PhD}^{1}$
}

Departments of ${ }^{1}$ Neurosurgery and ${ }^{2}$ Neurology, ljinkai Takeda General Hospital, Kyoto, Japan; and ${ }^{3}$ Emergency Medical Center, ljinkai Takeda General Hospital, Kyoto, Japan

\begin{abstract}
BACKGROUND Intravenous tissue plasminogen activator (IV t-PA) is effective for the treatment of distal artery occlusion. However, after the use of IV t-PA, vascular occlusion in unaffected territories may occur. Early recurrent ischemic stroke (ERIS) is defined as the occurrence of new neurological symptoms that suggest the involvement of initially unaffected vascular territories after intravenous thrombolysis (IVT). The authors reviewed the cases of ERIS that occurred within 24 hours after treatment with IVT.

OBSERVATIONS A 75-year-old woman with occlusion in the M2 segment of the left middle cerebral artery (MCA) was treated with IV t-PA. However, 360 minutes later, the patient presented with occlusion in the M1 distal segment of the contralateral side, the right MCA, which was recanalized by endovascular treatment. Her modified Rankin Scale score was 4; however, aphasia was not observed. She was transferred to a rehabilitation hospital after 3 months.
\end{abstract}

LESSONS ERIS is an extremely rare but catastrophic event. The underlying mechanism of ERIS most likely involves the disintegration and subsequent scattering of a preexisting intracardiac thrombus. Hence, caution must be used when managing not only hemorrhagic complications but also ischemic complications after IV t-PA. Endovascular management may be the only effective treatment for this type of large vessel occlusion.

https://thejns.org/doi/abs/10.3171/CASE20175

KEYWORDS tissue plasminogen activator; ischemic complication; endovascular treatment

Intravenous tissue plasminogen activator (IV t-PA) is effective for the treatment of distal artery occlusion. ${ }^{1,2}$ We present a case of occlusion in the M2 segment of the left middle cerebral artery (MCA) treated with IV t-PA. However, 360 minutes after treatment, the patient presented with occlusion in the distal M1 segment of the contralateral side, the right MCA, which was treated using the endovascular technique. Other cases of ischemic stroke with vascular occlusion in unaffected territories occurring within 24 hours of treatment with intravenous thrombolysis (IVT) were reviewed.

\section{Illustrative Case}

A 75-year-old woman with a history of diabetes mellitus and hyperlipidemia was admitted 20 minutes after the sudden onset of left hemiparesis and aphasia. Her National Institutes of Health Stroke Scale
(NIHSS) score was 23, and she presented with atrial fibrillation. Computed tomography (CT) scans on admission did not show any acute ischemic signs. Subsequent three-dimensional CT angiography revealed occlusion in the M2 segment of the left MCA (Fig. 1A). However, it did not reveal any stenoses or ulceration in the bilateral carotid artery of the cervical segment or any large plaques in the upper portion of the aortic arch. IV t-PA was administered 133 minutes after the onset of the event. Aphasia and level of consciousness gradually improved while the patient was in the intensive care unit, and her NIHSS score decreased to 8 . However, 360 minutes after administration of IV t-PA, she experienced rightward conjugate deviation and left hemiparesis, and her NIHSS score increased to 38. Emergency diffusion-weighted imaging revealed an acute ischemic lesion in the right corona radiata and a small ischemic lesion in the left hemisphere (Fig. 1B). Magnetic

ABBREVIATIONS CT = computed tomography; ERIS = early recurrent ischemic stroke; ICH = intracranial hemorrhage; IV t-PA = intravenous tissue plasminogen activator; IVT = intravenous thrombolysis; MCA = middle cerebral artery; mRS = modified Rankin Scale; MT = mechanical thrombectomy; NIHSS = National Institutes of Health Stroke Scale; PCI = percutaneous coronary intervention; STEMI = ST-elevation myocardial infarction; TICI = thrombolysis in cerebral infarction. INCLUDE WHEN CITING Published April 12, 2021; DOI: 10.3171/CASE20175.

SUBMITTED December 28, 2020. ACCEPTED January 18, 2021.

(C) 2021 The authors, CC BY-NC-ND 4.0 (http://creativecommons.org/licenses/by-nc-nd/4.0/). 

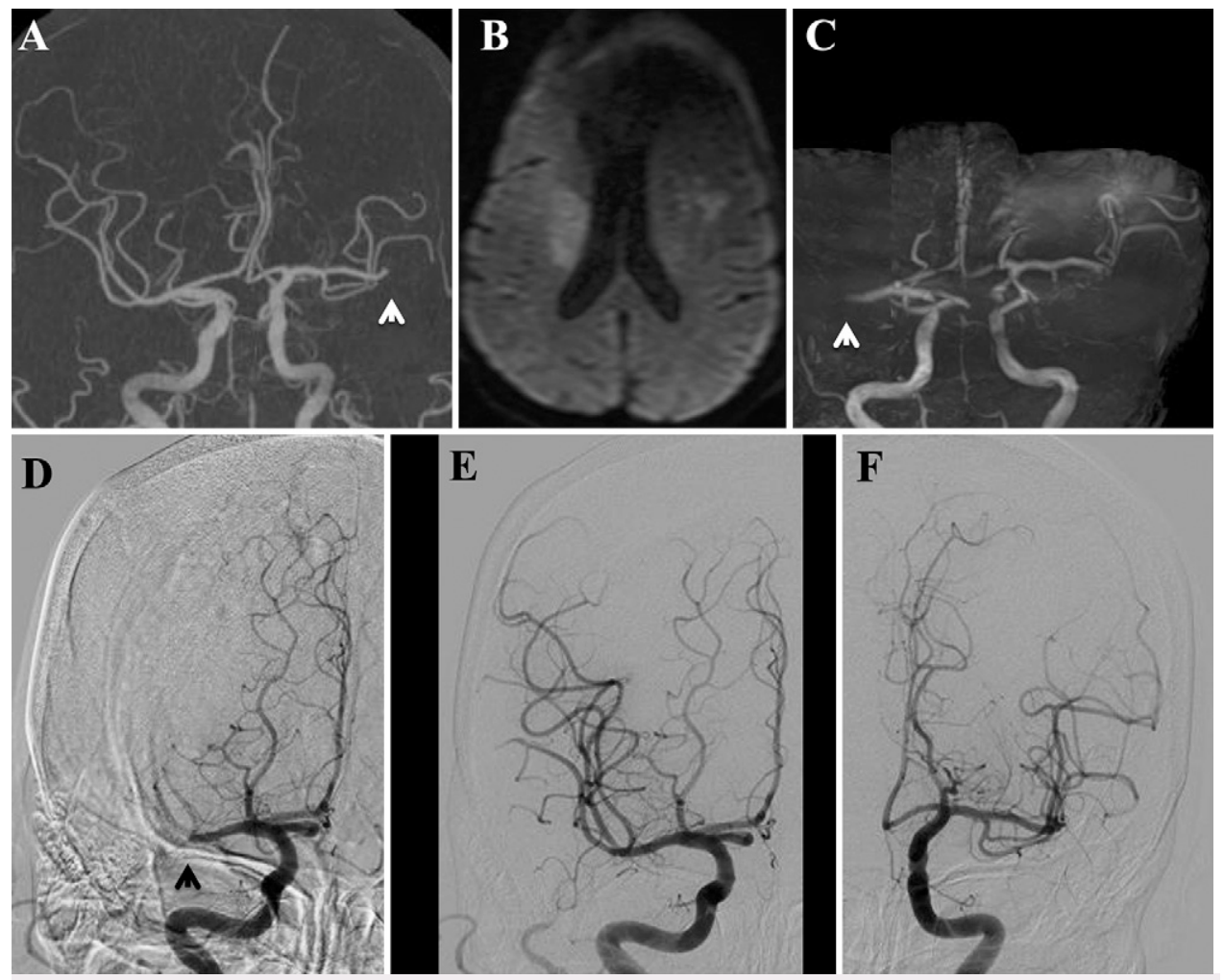

FIG. 1. A: Three-dimensional CT angiography of the intracranial lesion revealed occlusion at the M2 segment of the left MCA (arrowhead). B: Diffusion-weighted imaging performed 6 hours after treatment with IV t-PA showed an acute ischemic lesion in the right corona radiata and a small ischemic lesion in the left hemisphere. C: Magnetic resonance angiography showed recanalization of the M2 segment of the MCA and occlusion in the M1 distal segment of the right MCA (arrowhead). D: The right internal carotid artery (ICA) angiogram revealed occlusion in the distal M1 segment of the MCA (arrowhead). E: Right ICA angiogram after thrombectomy revealed revascularization of the occluded MCA. F: Left ICA angiogram showed no residual stenosis of the M2 segment of the MCA after treatment with IV t-PA.

resonance angiography showed recanalization of the M2 segment of the MCA and occlusion in the M1 distal segment of the right MCA (Fig. 1C). The patient was then referred for endovascular treatment because the event occurred after treatment with IV t-PA. Angiography revealed occlusion in the $M 1$ distal segment of the right $M C A$ (Fig. 1D). The Penumbra System 5MAX ACE and 3MAX catheters were used to navigate the M1 segment of the MCA. The aspiration catheter of $5 \mathrm{MAX}$ could easily navigate the M1 distal segment. The first aspiration via the 5MAX removed the thrombus, and thrombolysis in cerebral infarction $(\mathrm{TICl})$ grade 3 revascularization of the affected MCA territory was achieved (Fig. 1E). A left internal carotid artery angiogram also showed $\mathrm{TICl}$ grade 3 revascularization of the M2 segment of the left MCA (Fig. 1F). Magnetic resonance imaging performed on the day after admission revealed infarctions in the right MCA territory and small infarctions in the left MCA territory. The patient's modified Rankin Scale (mRS) score was 4; however, aphasia was not observed. She was transferred to a rehabilitation hospital 3 months later.

\section{Discussion}

According to Georgiadis et al., ${ }^{3}$ early recurrent ischemic stroke (ERIS) is defined as the occurrence of new neurological symptoms that suggest the involvement of initially unaffected vascular territories and evidence of corresponding ischemic lesions on cranial CT scans in the absence of intracranial hemorrhage $(\mathrm{ICH})$. To the best of our knowledge, only 10 cases exist, $^{4-7}$ including 2 case series ${ }^{3,8}$ of ERIS occurring within 24 hours after treatment with IVT (Table 1). In those 2 case series, the incidence rates of ERIS were $0.59 \%{ }^{3}$ and $2.6 \%{ }^{8}$ In most cases, ERIS occurred within 60 minutes after treatment with IVT. However, no relationship seemed to exist between the site of the first occlusion and the second. Seven cases involved patients with an mRS score of 6 with conservative therapy. The present study involves the third case in which the patient survived and was treated with an endovascular technique. The first patient was treated with intraarterial thrombolysis, which resulted in an mRS score of $6 ;^{8}$ the second patient was treated with endovascular aspiration, which resulted in an $\mathrm{mRS}$ score of $4 .^{4}$ That study was written in the Japanese language, however.

The underlying mechanism of ERIS after treatment with IVT for acute ischemic stroke most likely involves the disintegration and subsequent scattering of preexisting intracardiac thrombus. ${ }^{3,9}$ The source of the embolism in our patient's second event may have been related to the preexisting intracardiac thrombus. However, in 
TABLE 1. Eleven cases of ERIS within 24 hours after treatment with IVT

\begin{tabular}{|c|c|c|c|c|c|c|c|c|c|c|}
\hline Case No. & $\begin{array}{c}\text { Author \& } \\
\text { Year }\end{array}$ & $\begin{array}{l}\text { Age (yrs), } \\
\text { Gender }\end{array}$ & $\begin{array}{l}\text { Risk } \\
\text { Factor }\end{array}$ & $\begin{array}{l}\text { Site of } \\
\text { First } \\
\text { Occlusion }\end{array}$ & $\begin{array}{l}\text { Onset to } \\
\text { Initial t-PA } \\
\text { (mins) }\end{array}$ & $\begin{array}{l}\text { Site of Second } \\
\text { Occlusion }\end{array}$ & $\begin{array}{l}\text { Initial t-PA } \\
\text { to Second } \\
\text { Occlusion } \\
\text { (mins) }\end{array}$ & Treatment & Image & Outcome \\
\hline 1 & $\begin{array}{c}\text { Kissela et al., } \\
2001^{5}\end{array}$ & $80, F$ & $\mathrm{AF}$ & $\begin{array}{c}\text { Rt M1 } \\
\text { distal susp }\end{array}$ & 165 & BA distal susp & 120 & Cons & $\begin{array}{c}\text { BA } \\
\text { occlusion }\end{array}$ & Death \\
\hline 2 & $\begin{array}{l}\text { Lai \& Hu, } \\
2006^{6}\end{array}$ & $81, M$ & AF, HT & $\begin{array}{c}\text { Rt M1 } \\
\text { proximal } \\
\text { susp }\end{array}$ & 120 & $\begin{array}{l}\text { Lt M1 proximal } \\
\text { susp }\end{array}$ & 62 & Cons & $\begin{array}{l}\text { Bilat MCA } \\
\text { infarction }\end{array}$ & ND \\
\hline 3 & $\begin{array}{l}\text { Georgiadis } \\
\text { et al., } 2006^{3}\end{array}$ & $72, M$ & HT, DM & $\begin{array}{l}\text { Lt ICA } \\
\text { susp }\end{array}$ & 170 & $\begin{array}{c}\text { Rt M1 proximal, } \\
\text { rt PICA }\end{array}$ & 40 & Cons & $\begin{array}{c}\text { Multiple } \\
\text { infarction }\end{array}$ & Death \\
\hline 4 & $\begin{array}{l}\text { Georgiadis } \\
\text { et al., } 2006^{3}\end{array}$ & $78, \mathrm{~F}$ & $\mathrm{HT}$ & $\begin{array}{c}\text { Lt M1 } \\
\text { proximal } \\
\text { susp }\end{array}$ & 175 & Lt ICA, rt ICA & 50 & Cons & $\begin{array}{l}\text { Bilat MCA } \\
\text { infarction }\end{array}$ & Death \\
\hline 6 & $\begin{array}{c}\text { Awadh et al., } \\
2010^{8}\end{array}$ & $80, F$ & $A F, I H D$ & Lt MCA & 160 & $\mathrm{BA}$ & 80 & ET & $\begin{array}{c}\text { BA } \\
\text { occlusion }\end{array}$ & Death \\
\hline 7 & $\begin{array}{c}\text { Awadh et al., } \\
2010^{8}\end{array}$ & $64, F$ & HT & Rt MCA & 210 & Lt MCA & 60 & Cons & $\begin{array}{l}\text { Bilat MCA } \\
\text { infarction }\end{array}$ & Death \\
\hline 8 & $\begin{array}{c}\text { Awadh et al., } \\
2010^{8}\end{array}$ & $62, \mathrm{M}$ & $\mathrm{AF}, \mathrm{HOCM}$ & Lt MCA & 165 & Rt MCA & 45 & Cons & $\begin{array}{l}\text { Bilat MCA } \\
\text { infarction }\end{array}$ & Death \\
\hline 9 & $\begin{array}{c}\text { Awadh et al., } \\
2010^{8}\end{array}$ & $74, \mathrm{M}$ & DM, IHD & Lt MCA & 150 & ND & 40 & Cons & $\begin{array}{l}\text { Lt MCA, rt } \\
\text { PCA }\end{array}$ & Death \\
\hline 10 & $\begin{array}{c}\text { Hanakawa } \\
\text { et al., } 2017^{4}\end{array}$ & $82, F$ & $\mathrm{AF}$ & $\begin{array}{c}\text { Rt M1 } \\
\text { distal susp }\end{array}$ & 210 & Lt MCA distal & 55 & ET & $\begin{array}{c}\text { Bilat basal } \\
\text { ganglia }\end{array}$ & mRS 4 \\
\hline
\end{tabular}

$\mathrm{AF}=$ atrial fibrillation; $\mathrm{BA}=$ basilar artery; $\mathrm{CHF}=$ chronic heart failure; Cons = conservative treatment; $\mathrm{DM}=$ diabetes mellitus; $\mathrm{ET}=$ endovascular treatment;

$\mathrm{HL}=$ hyperlipidemia; $\mathrm{HOCM}=$ hypertrophic obstructive cardiomyopathy; $\mathrm{HT}=$ hypertension; ICA = internal carotid artery; IHD = ischemic heart disease;

$\mathrm{ND}=$ not described; $\mathrm{PCA}=$ posterior cerebral artery; PICA = posterior inferior cerebellar artery; susp = suspected site of the occluded vessel based on the images in the papers.

the acute setting for stroke management, it may be impossible to evaluate the size and fragility of a thrombus in the heart. Embolic stroke is a well-recognized event, but it rarely occurs in patients undergoing IVT for acute myocardial infarction. ${ }^{9-11}$ The incidence rate was reported to be between $0.4 \%$ and $0.7 \%$ during hospital stay. ${ }^{12}$ Primary percutaneous coronary intervention $(\mathrm{PCl})$ is defined as coronary angioplasty/stenting without prior IVT for ST-elevation myocardial infarction (STEMI). ${ }^{13,14}$ In the early 2000 s, primary $\mathrm{PCl}$ was considered more effective in treating STEMI than IVT. ${ }^{14}$ The primary $\mathrm{PCl}$ protocol seemed to be standard management for STEMI in the 2010s in Japan. ${ }^{15}$

It is widely accepted that IV t-PA is particularly effective in the treatment of distal artery occlusion. ${ }^{1,2}$ Now, however, neurointerventionalists can safely perform procedures on smaller and distal arteries using new devices for endovascular therapy. ${ }^{2,16}$ A meta-analysis of mechanical thrombectomy (MT) for the M2 segment of the MCA reported that the rate of IV t-PA received before MT was $57 \%$, the symptomatic $\mathrm{ICH}$ rate was $16 \%$, and the recanalization rate of $\mathrm{TICl}$ grade $2 \mathrm{~b} / 3$ was $81 \%{ }^{16}$ Takagi et al. reported that the administration of preprocedural IV t-PA did not increase the incidence of $\mathrm{ICH}$ in total; however, it increased the incidence of symptomatic ICH in patients with $\mathrm{M} 2$ occlusion. ${ }^{17}$ The "IV t-PA skip and direct MT method," also referred to as "primary MT," may be a treatment option for M2 occlusion. In our patient, the occurrence of this rare ischemic event and hemorrhagic complications associated with IV t-PA might have been prevented.

\section{Observations}

Only 10 cases of ERIS occurring within 24 hours after treatment with IV t-PA have been noted. ERIS is an extremely rare but catastrophic event. The underlying mechanism of ERIS most likely involves the disintegration and subsequent scattering of preexisting intracardiac thrombus. Hence, caution must be used when managing not only hemorrhagic complications but also ischemic complications after treatment with IV t-PA. Endovascular management may be the only effective treatment for this type of large vessel occlusion.

\section{Lessons}

IV t-PA may cause ERIS, which is an extremely rare but catastrophic event. Caution must be used when treating not only 
hemorrhagic complications but also ischemic complications after treatment with IV t-PA. Endovascular management may be the only effective treatment for this type of large vessel occlusion.

\section{References}

1. Bhatia R, Hill MD, Shobha N, et al. Low rates of acute recanalization with intravenous recombinant tissue plasminogen activator in ischemic stroke: real-world experience and a call for action. Stroke. 2010;41(10):2254-2258.

2. Grossberg JA, Rebello LC, Haussen DC, et al. Beyond large vessel occlusion strokes: distal occlusion thrombectomy. Stroke. 2018;49(7):1662-1668.

3. Georgiadis D, Engelter S, Tettenborn B, et al. Early recurrent ischemic stroke in stroke patients undergoing intravenous thrombolysis. Circulation. 2006;114(3):237-241.

4. Hanakawa K, Tanakan K, Nagashima R, et al. One instance of a patient with brain embolism occurring in the contralateral middle cerebral artery during the t-PA intravenous injection. Article in Japanese. Jpn J Stroke. 2017;39(6):441-445.

5. Kissela BM, Kothari RU, Tomsick TA, et al. Embolization of calcific thrombi after tissue plasminogen activator treatment. J Stroke Cerebrovasc Dis. 2001;10(3):135-138.

6. Lai CC, Hu CJ. A left MCA territory infarction during intravenous recombinant tissue plasminogen activator therapy for right MCA territory ischaemic stroke. Emerg Med J. 2006;23(2):e11.

7. Yalcin-Cakmakli G, Akpinar E, Topcuoglu MA, Dalkara T. Right internal carotid artery occlusion during intravenous thrombolysis for left middle cerebral artery occlusion. J Stroke Cerebrovasc Dis. 2009;18(1):74-77.

8. Awadh M, MacDougall N, Santosh C, et al. Early recurrent ischemic stroke complicating intravenous thrombolysis for stroke: incidence and association with atrial fibrillation. Stroke. 2010;41(9):1990-1995.

9. Chang GY. An ischemic stroke during intravenous recombinant tissue plasminogen activator infusion for evolving myocardial infarction. Eur J Neurol. 2001;8(3):267-268.

10. Derex L, Nighoghossian N, Perinetti M, et al. Thrombolytic therapy in acute ischemic stroke patients with cardiac thrombus. Neurology. 2001;57(11):2122-2125.

11. Stafford PJ, Strachan CJL, Vincent R, Chamberlain DA. Multiple microemboli after disintegration of clot during thrombolysis for acute myocardial infarction. BMJ. 1989;299(6711):1310-1312.

12. Feruglio GA, Lotto $A$, Rovelli $F$, et al. GISSI-2: A factorial randomised trial of alteplase versus streptokinase and heparin versus no heparin among 12,490 patients with acute myocardial infarction. Lancet. 1990;336(8707):65-71.
13. Ellis SG. A clinical trial comparing primary coronary angioplasty with tissue plasminogen activator for acute myocardial infarction. N Engl J Med. 1997;336(23):1621-1628.

14. Keeley EC, Boura JA, Grines CL. Primary angioplasty versus intravenous thrombolytic therapy for acute myocardial infarction: a quantitative review of 23 randomised trials. Lancet. 2003;361 (9351):13-20.

15. Yasuda S, Nakao K, Nishimura K, et al. The current status of cardiovascular medicine in Japan-Analysis of a large number of health records from a nationwide claim-based database, JROADDPC. Circ J. 2016;80(11):2327-2335.

16. Saber H, Narayanan S, Palla M, et al. Mechanical thrombectomy for acute ischemic stroke with occlusion of the M2 segment of the middle cerebral artery: a meta-analysis. J Neurointerv Surg. 2018; 10(7):620-624

17. Takagi T, Yoshimura S, Uchida K, et al. Intravenous tissue plasminogen activator before endovascular treatment increases symptomatic intracranial hemorrhage in patients with occlusion of the middle cerebral artery second division: subanalysis of the RESCUE-Japan Registry. Neuroradiology. 2016;58(2):147-153.

\section{Disclosures}

The authors report no conflict of interest concerning the materials or methods used in this study or the findings specified in this paper.

\section{Author Contributions}

Conception and design: Sugie, Yamada, Miyake, Ito, Tanaka, Nomura, Fujita, Nakatani, Kawanishi. Acquisition of data: Sugie, Miyake, Ito, Tanaka, Nomura, Fujita, Nakatani. Analysis and interpretation of data: Sugie, Miyake, Ito, Tanaka, Nomura, Fujita, Nakatani. Drafting the article: Sugie, Ito, Tanaka, Nomura, Kawanishi. Critically revising the article: Sugie, Miyake, Ito, Tanaka, Nomura, Fujita, Nakatani. Reviewed submitted version of manuscript: Sugie, Ito, Tanaka, Nomura, Nakatani, Kawanishi. Approved the final version of the manuscript on behalf of all authors: Sugie. Statistical analysis: Ito, Tanaka, Nomura. Administrative/ technical/material support: Sugie, Miyake, Ito, Tanaka, Nomura, Fujita, Nakatani. Study supervision: Sugie, Yokoyama, Ito, Tanaka, Nomura, Kawanishi.

\section{Correspondence}

Akira Sugie: ljinkai Takeda General Hospital, Kyoto, Japan. neu055@ osaka-med.ac.jp. 